\title{
First record of the genus Vetulina Schmidt, 1879 (Porifera: Demospongiae: Sphaerocladina) from the Indian Ocean with the description of two new species: biogeographic and evolutionary significance
}

\author{
Andrzej Pisera $^{1}$ • Magdalena Lukowiak ${ }^{1}$ - Jane Fromont ${ }^{2}$ - Astrid Schuster ${ }^{3}$
}

Received: 24 August 2016 / Revised: 23 October 2016 / Accepted: 10 February 2017 / Published online: 1 March 2017

(C) The Author(s) 2017. This article is published with open access at Springerlink.com

\begin{abstract}
Two new species of the genus Vetulina Schmidt, 1879 (Demospongiae, Vetulinidae, Sphaerocladina) were found off the coast of Western Australia (Indian Ocean). This genus is characterized by acrepid polyaxial desmas (sphaeroclones) equipped with arborescent branched outgrowths with spine-like processes and isometric styles as microscleres. Vetulina indica sp. nov. is an irregular, laterally folded ear-shaped cup with smooth surfaces, and V. rugosa sp. nov. is similar in shape but with a distinctive ribbed inner surface. Both species are very similar in spicule composition, but are distinguished by their gross morphology and pattern of canal openings on the surface. Despite the fact that we could not distinguish the two specimens based on molecular (CO1) data, we consider them as two separate species based on the morphological species concept. Our molecular phylogeny confirms again that Vetulina is sister to spongillids (freshwater sponges). This is the first occurrence of this genus outside the Caribbean Atlantic, and the first report from the Indian Ocean. Such a disjunct distribution is considered here to be a relict of a once widely distributed sponge population in the ancient Tethys Sea.
\end{abstract}

Communicated by P. Martinez Arbizu

This article is registered in ZooBank under urn: 1sid:zoobank.org: pub:0895227E-C2F8-41F3-B227-036C80BF83A5

Andrzej Pisera

apis@twarda.pan.pl

1 Institute of Paleobiology, Polish Academy of Sciences, ul. Twarda 51/55, 00-818 Warszawa, Poland

2 Department of Aquatic Zoology, Western Australian Museum, Locked Bag 49, Welshpool DC, WA 6986, Australia

3 Department of Earth \& Environmental Sciences, Palaeontology and Geobiology, Ludwig-Maximilians-Universität München, Richard-Wagner-Str. 10, 80333 Munich, Germany
Keywords Lithistids · Vetulinidae · Vetulina indica sp. nov · Vetulina rugosa $\mathrm{sp}$. nov $\cdot$ Tethys Sea

\section{Introduction}

Lithistid sponges are known from almost all temperate and tropical oceans but are generally restricted to deeper water of greater than $80 \mathrm{~m}$ depth (Kelly 2007). The best-described lithistid faunas occur in the tropical western Atlantic (see Pomponi et al. 2001 and references therein) and south-west Pacific (see Kelly 2007 and references therein).

Lithistids have rigid skeletons comprised of interlocking desmas and are consequently easily fossilized. However, there is no reliable fossil record of Vetulina known to date, as the report by Moret (1926) of a sponge from the Turonian (Late Cretaceous) of France is based solely on general morphological resemblance (no spicules are known). Lithistids with sphaeroclonar desmas are known from Jurassic and Cretaceous rocks (with one Eocene occurrence in Italy; Frisone et al. 2016), mainly in Europe, and are attributed to 10 genera (Reid 2004). The first Mesozoic lithistid demosponge with sphaeroclonar desmas is from the Bathonian (Middle Jurassic) of India (Mehl and Fürsich 1997). There are even Palaeozoic lithistid demosponges bearing sphaeroclonar desmas grouped in the family Astylospongiidae Zittel 1877 (Ordovician-Permian) (Finks and Rigby 2004), but their relationship to younger Mesozoic and Recent forms is unclear, due to the large ( $200 \mathrm{Ma}$ years) stratigraphic gap that separates them.

Until recently, lithistids were grouped as "lithistid Demospongiae' for convenience, but were known to be polyphyletic (Pisera and Lévi 2002). With recent molecular studies, this has been formally abandoned and lithistid species have been allocated to 13 families in 4 orders (Morrow and 
Cárdenas 2015; Schuster et al. 2015). The Vetulinidae Von Lendenfeld 1903 are a single family in the Sphaerocladina, an order that already existed in the fossil classification (Morrow and Cárdenas 2015).

The genus Vetulina Schmidt 1879 is currently the only living representative of a once more diversified Mesozoic group of lithistid demosponges with sphaeroclonar desmas (Pisera and Lévi 2002; Reid 2004 with references), that have older Paleozoic relatives (Pisera 2002). So far, the only known extant representative of this genus is Vetulina stalactites Schmidt 1879 reported from Barbados at $180 \mathrm{~m}$ depth (Schmidt 1879; Sollas 1885, 1888; Soest and Stentoft 1988; Pisera and Lévi 2002). However, V. stalactites is rarely reported and consequently poorly known.

In this paper, we report two new species of Vetulina, describing their morphology, illustrating their spiculation in detail, and discussing their distribution and their molecular barcodes.

\section{Materials and methods}

The specimens were collected during an expedition on the RV Southern Surveyor in 2007 which sampled the northwestern continental shelf margin of Western Australia $\left(12^{\circ}-22^{\circ} \mathrm{S}\right)$, in the eastern Indian Ocean (Fig. 1; Fromont et al. 2012). Equipment used were a Sherman sled and beam trawl that sampled hard substrates. Voucher specimens were photographed on deck, labelled and preserved in $75 \%$ ethanol. They are housed in the collections of the Western Australian Museum Harry Butler Research Centre, Welshpool.

\section{Systematic description}

\section{Class Demospongiae}

Order Sphaerocladina Schrammen 1924

Family Vetulinidae Lendenfeld 1903

Emended diagnosis: Lithistid Demospongiae with acrepid polyaxial (sphaeroclones to astroclones) desmas; no other megascleres; microscleres when present are microstyles or ?strongyles (modified after Pisera and Lévi 2002).

Remarks: Emendation to the diagnosis was required as the new species described here have microscleres that were not included in the family diagnosis published in the Systema Porifera (Pisera and Lévi 2002). Microscleres were not reported in the original description of the type of the genus, V. stalactites Schmidt (1879), a specimen which was poorly preserved. However, they were described from better preserved specimens investigated by Sollas $(1885,1888)$, although they were interpreted later as contamination (Pisera and Lévi 2002). Sollas (1888) described them as cylindrical strongyles, $40-350 \mu \mathrm{m}$ in size. However, the lack of illustrations depicting the morphology of these spicules precludes deciding whether or not they are strongyles. On the other hand, in his earlier publication on $V$. stalactites, Sollas (1885) never mentioned strongyles in his descriptions and only illustrated "the simple cylindrical spicules" as belonging to V. stalactites (Sollas 1885: pl. IV, fig. 2). Indeed, they resemble strongyles more than any other spicule type, including the styles found in this study, but the minimum attention given to describe them, and a single illustrated spicule, allows us to have justified doubts about their real nature.

The size of the microscleres from the studied specimens $(80-110 \mu \mathrm{m})$ may raise some doubts as to whether they are micro- or megascleres. The threshold between micro- and megascleres is generally accepted as $50 \mu \mathrm{m}$ (van Soest et al. 2012), although there are some spicules, such as sterrasters and selenasters, that are considered to be microscleres despite their large size. In the species described here, the size is not decisive as we consider the position/role of the spicules in the skeleton to conform more to the definition of microscleres.

Genus Vetulina Schmidt 1879

Diagnosis: As for the family.

Remarks: As for the family. The only fossil record of the genus from the upper Cretaceous rocks by Moret (1926) is considered here to be unreliable because it is based solely on similarities of general morphology (no spicules are known).

Type species: Vetulina stalactites Schmidt 1879 (by monotypy).

Vetulina indica sp. nov.

Figs. 2a, 3a-c, 4, 5, 6

Holotype: Western Australia, Ashmore Reef (12 $26^{\prime} 42^{\prime \prime} \mathrm{S}$, $123^{\circ} 36^{\prime} 03^{\prime \prime} \mathrm{E}$ to $\left.12^{\circ} 26^{\prime} 58^{\prime \prime} \mathrm{S}, 123^{\circ} 36^{\prime} 35^{\prime \prime} \mathrm{E}\right), 95 \mathrm{~m}$, M. Salotti on RV Southern Surveyor, beam trawl, SS0507/188, 06/07/ 2007 (WAM Z35842).

Diagnosis: Laterally flattened ear-shaped low cup with smooth surfaces; no special ectosomal spicules; choanosomal spicules acrepid polyaxial desmas (sphaeroclones) with smaller arborescent outgrowths with minute spines; microscleres straight to slightly bent isodiametric styles with mucronate tips.

Description: Laterally flattened irregular, convoluted, earshaped cup with a smaller cup outgrowth at the base (Fig. 2a). Dimensions of specimen: $10 \mathrm{~cm}$ high, apically $10 \times 14 \mathrm{~cm}$ wide. Small basal lobe: $4 \mathrm{~cm}$ high, $6 \times 3 \mathrm{~cm}$ wide. Cup walls $1 \mathrm{~cm}$ thick with convoluted margins slightly sloping towards the outer surface. Both surfaces smooth. Outer surface porous with visible growth lines (Fig. $3 \mathrm{~b}, \mathrm{c}$ ) and large pores (?oscules) from $100-400 \mu \mathrm{m}$ in diameter, irregularly distributed (Figs. 3c. 4a, b), surrounded by rare styles (Fig. 4b). Inner surface very smooth (Fig. 3a) with rare low knobs $(<1 \mathrm{~mm}$ high, up to $3 \times 3 \mathrm{~mm}$ wide) and small openings (?ostia) irregularly distributed, up to $50 \mu \mathrm{m}$ in diameter (Fig. 5a-c). Live color light yellow, fawn in ethanol (Fig. 2a). 


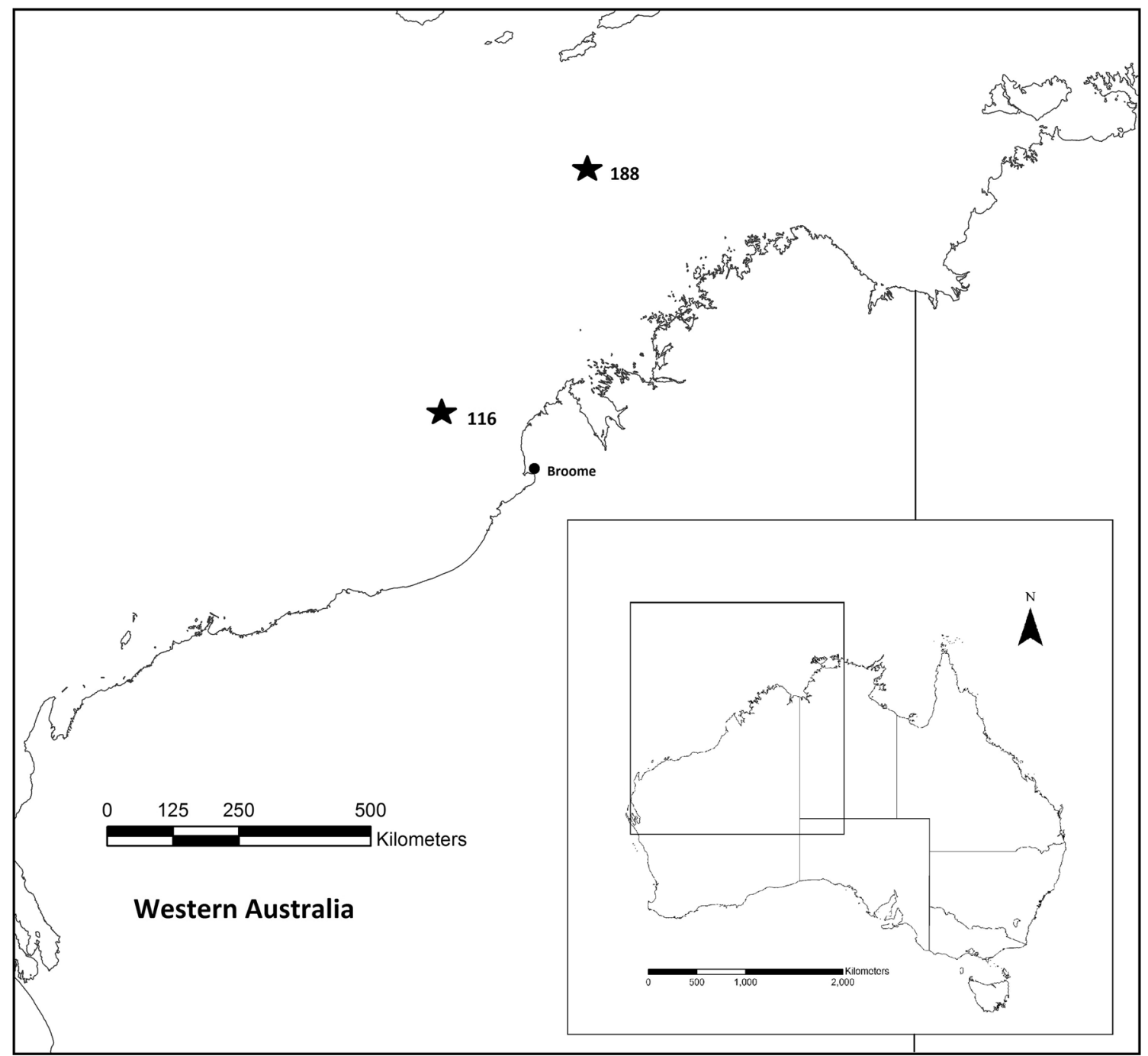

Fig. 1 Locations of Station 116 (specimen WAM Z36103) and Station 188 (specimen WAM 35842). Collection sites marked with asterisks

Choanosomal spicules acrepid polyaxial desmas (sphaeroclones) to $250 \mu \mathrm{m}$ diameter (Figs. 4e, f. 6c-e). External surface skeleton very dense network of desmas surrounding densely and regularly distributed canal openings about $100-400 \mu \mathrm{m}$ in diameter (Fig. 4c). Globular centers of the sphaeroclones covered by a dense irregular net of loosely interwoven spinose finger-like outgrowths (Fig. 4e, f). Internal surface similar in character but openings more densely distributed (Fig. $5 \mathrm{~d}-\mathrm{f}$ ) and measure only $50 \mu \mathrm{m}$ in diameter. Globular centers not visible on desmas from inner side and spinose finger like outgrowths irregular in character, resembling rhizoclones.

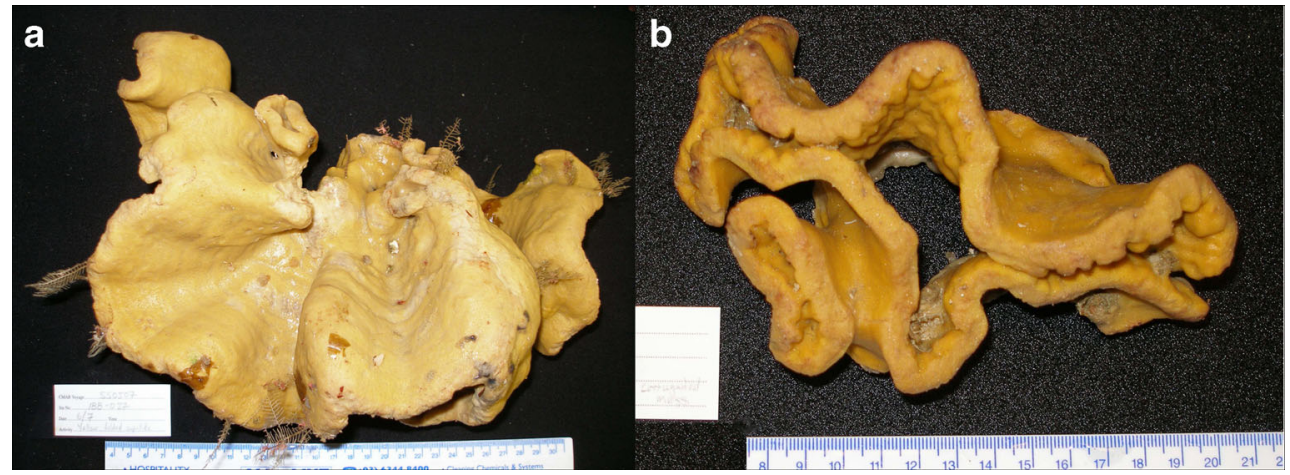

Fig. 2 Deck photos of a Vetulina indica sp. nov. and b V. rugosa sp. nov 
Fig. 3 Morphology of Vetulina indica: a top view, $\mathbf{b}$ side view, $\mathbf{c}$ detail of outer wall; $V$. rugosa: d top view, e side view, $\mathbf{f}$ detail of inner wall. Scale bars $2 \mathrm{~cm}$
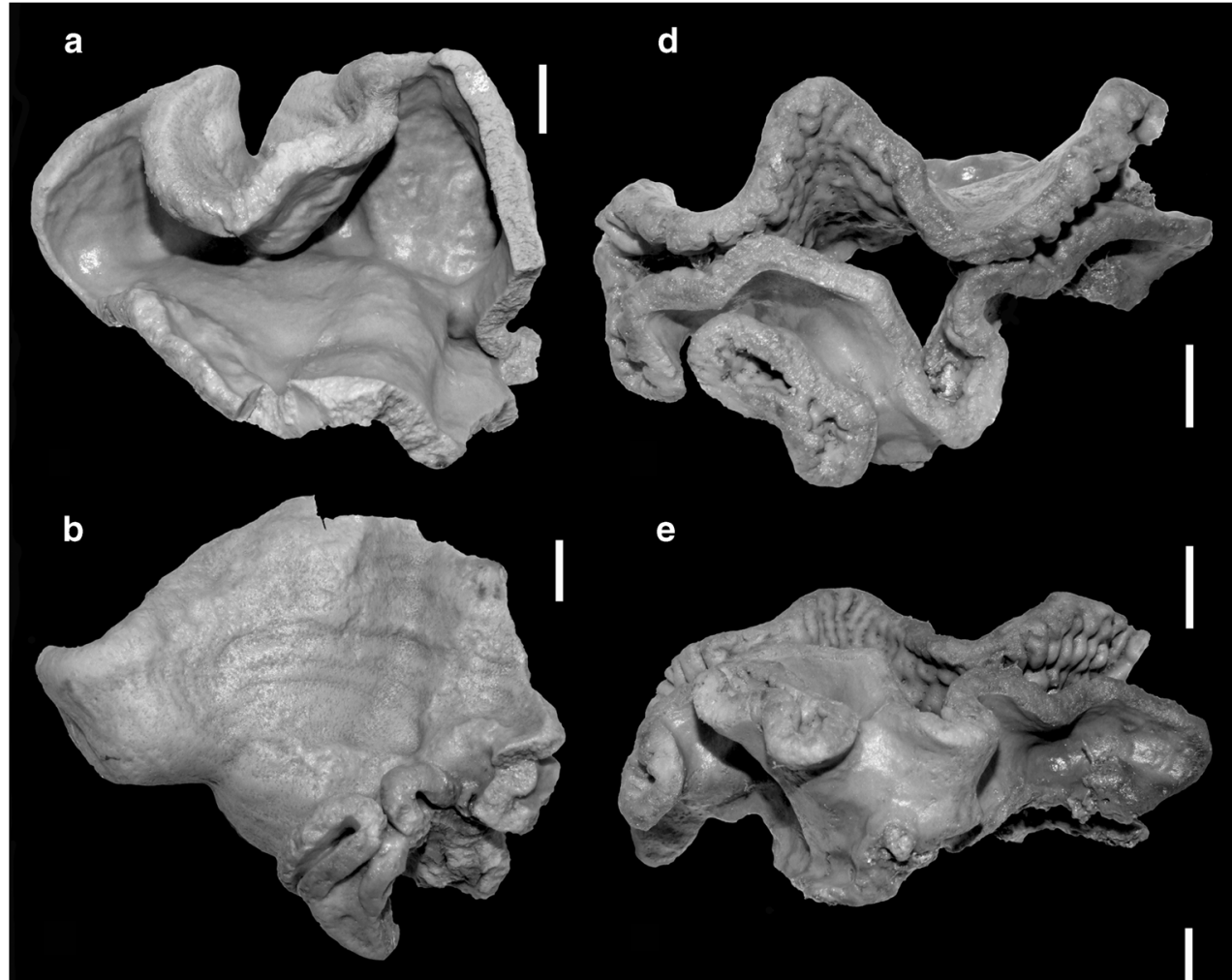

e

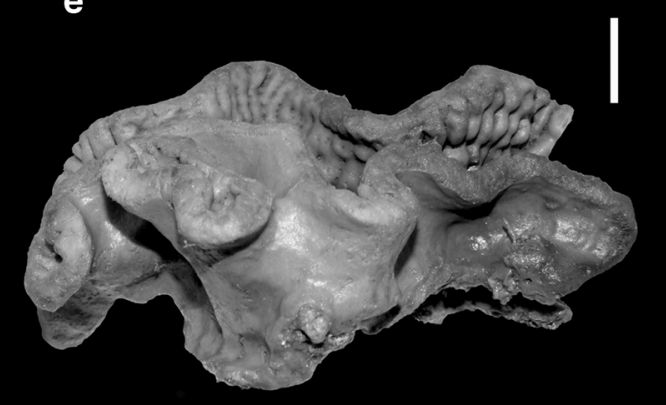

C

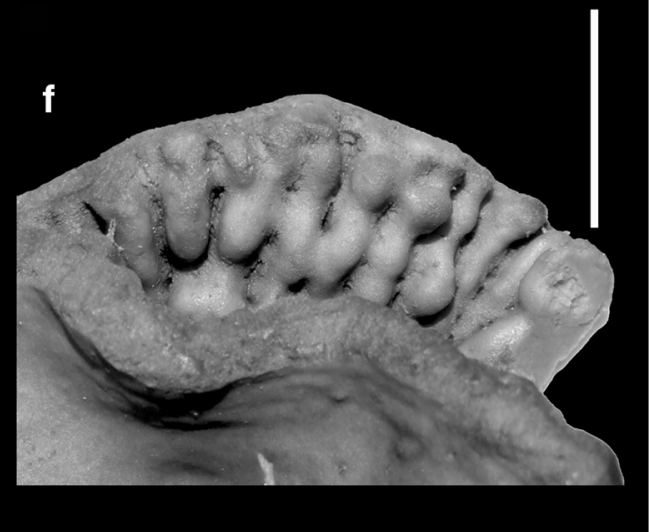

Desmas visible on the outer surface of the choanosomal skeleton have a globular center with several (3-6) main arms (directed inside the wall) densely covered with strongly branched outgrowths with many minute spines arranged apically (Figs. 4f, 6a). Internally in the choanosomal skeleton, the centers of desmas have tubercles rather than branched outgrowths (Fig. 6b, c).

Microscleres are small styles about $80-110 \mu \mathrm{m}$ long and $5 \mu \mathrm{m}$ thick. The styles are straight to slightly curved and isodiametric (of equal thickness along the spicule, Fig. 6d, e). Tips are short and mucronate. Styles extend from the membranes around the ostia in the ectosomal membrane. Rare styles also occur on the inside of the choanosomal canals.

Ecology: The sponge occurred on rocky substrate with a sand veneer.

Distribution: Ashmore Reef, northwestern Australia, Indian Ocean.
Etymology: Named for the location of this species in the Indian Ocean: Vetulina indica.

Remarks: To date, there is only one species known within this family and genus, Vetulina stalactites Schmidt 1879 from the Caribbean. V. stalactites possesses acrepid polyaxial desmas with well-defined arms that may be sparsely tuberculated and/or spinose, similar to the desmas of $V$. indica sp. nov. However, the degree of tuberculation (and spines) is reduced in $V$. stalactites compared to $V$. indica $\mathrm{sp}$. nov. In addition, the species have widely disjunct distributions. Both are similar in displaying growth lines on the surface.

The immature desmas of $V$. indica sp. nov. have a hollow center (not shown, but see $V$. rugosa sp. nov. below) instead of an axial canal, also seen in $V$. stalactites and reported by Sollas (1885). Lithistid demosponges with rhizoclone desmas such as Leiodermatium, which may also form folded cups or ridges and have only desmas and sometimes oxeas, are often 
Fig. 4 Vetulina indica sp. nov.: a, b view of outer surface (a) note several large (?oscular) openings; b details of membrane bordering large openings (?oscula) with desmas visible beneath dermal membrane, and microstyles extending into the oscula, $\mathbf{c}-\mathbf{f}$ view of the outer surface after removal of organic material by acid treatment showing a dense desma (sphaeroclones) network forming the choanosomal skeleton. Note globular centers (e, f) covered with complex spinose branching outgrowths. Scale bars (a) $500 \mu \mathrm{m}$, (b) $100 \mu \mathrm{m}$, (c) $1 \mathrm{~mm}$, (d) $200 \mu \mathrm{m},(\mathbf{e}) 100 \mu \mathrm{m}$, (f) $50 \mu \mathrm{m}$
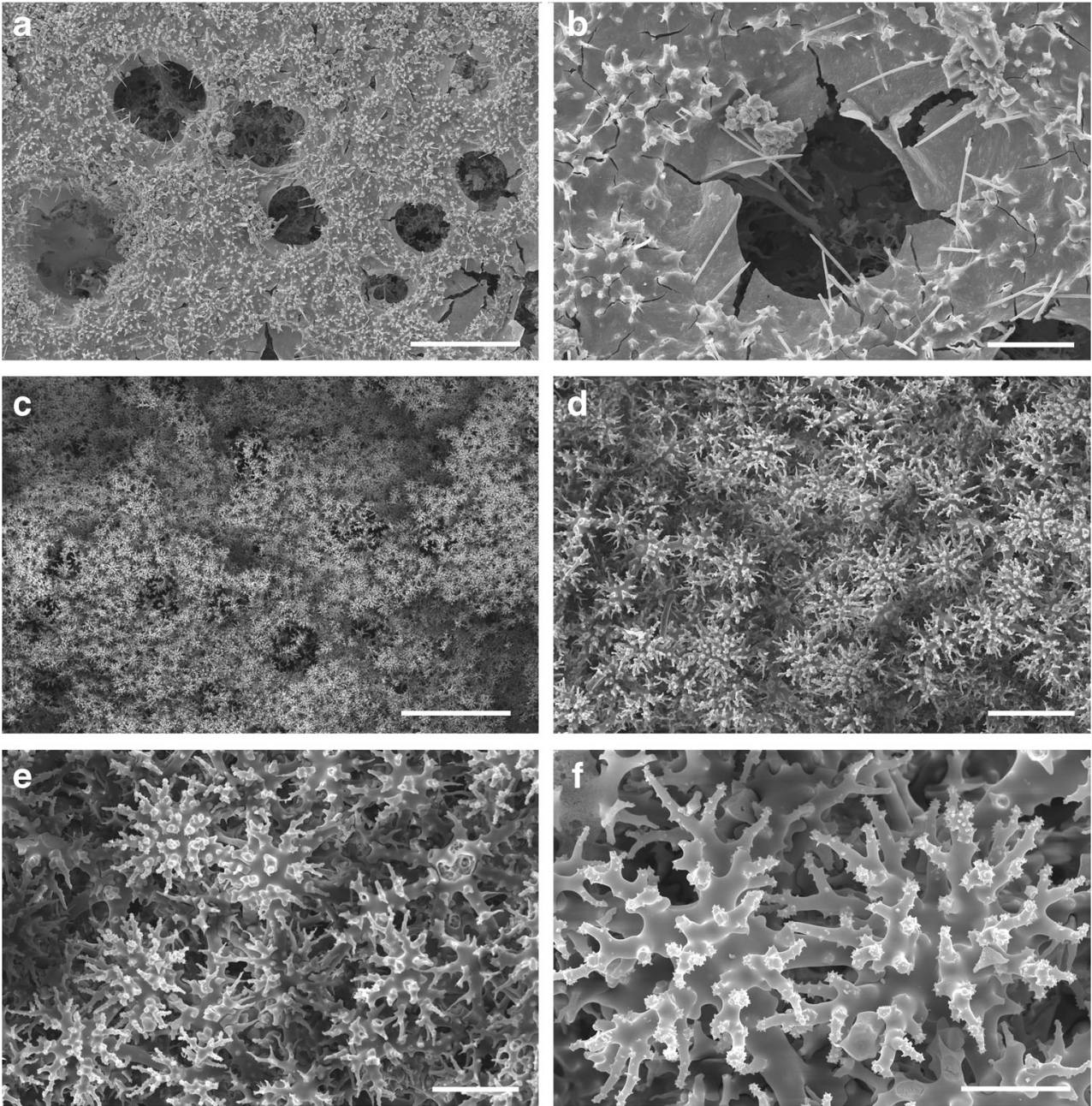

confused with Vetulina. This is due to the resemblance of the rhizoclones to sphaeroclones covered with arborescent spinose outgrowths. Additional remarks are provided after the description of $V$. rugosa sp. nov. below.

Vetulina rugosa sp. nov.

Figs. 2b, 3d-f, 7, 8, 9

Holotype: Western Australia, Broome $\left(16^{\circ} 45^{\prime} 09^{\prime \prime} \mathrm{S}\right.$, $121^{\circ} 02^{\prime} 48^{\prime \prime} \mathrm{E}$ to $\left.16^{\circ} 44^{\prime} 36^{\prime \prime} \mathrm{S}, 121^{\circ} 02^{\prime} 12^{\prime \prime} \mathrm{E}\right), 100-108 \mathrm{~m}, \mathrm{M}$. Salotti on RV Southern Surveyor, Sherman sled, station SS0507/116, 30/06/2007 (WAM Z36103).

Diagnosis: Convoluted laterally flattened cup with thick, vertical knobbed ribs on inner wall. No special ectosomal spicules; choanosmal spicules acrepid polyaxial desmas (sphaeroclones) with smaller arborescent outgrowths with minute spines; microscleres straight to slightly bent isodiametric styles with mucronate tips.

Description: Irregular, convoluted laterally flattened cup or bilobed ridge with a smaller laterally flattened cone-shaped outgrowth attached basally to the main sponge body. Dimensions of cup: $7 \mathrm{~cm}$ high, $14 \times 9 \mathrm{~cm}$ width. Small lateral cone $2 \mathrm{~cm}$ high, $4.5 \times 2.5 \mathrm{~cm}$ width. Central cavity of cup hollow, attachment to substrate via basal rim of cup walls. Sponge walls $1 \mathrm{~cm}$ thick, with flattened apical margins. Outer surface smooth and finely porous (Fig. 3d-f), with pores about $40 \mu \mathrm{m}$ in diameter; inner surface ribbed (Fig. 3d-f). Ribs are vertical and knobbed (Fig. 3f), extend $3 \mathrm{~mm}$ horizontally from the surface, are $7 \mathrm{~mm}$ wide and separated by narrow furrows containing lines of large openings (?oscules) up to $400 \mu \mathrm{m}$ in diameter (Fig. 8a). Ribs may disappear or fuse with neighboring ribs. Live color dull yellow, dark peach fawn in ethanol.

The choanosomal skeleton is composed of acrepid polyaxial desmas (sphaeroclones) up to $300 \mu \mathrm{m}$ in diameter (Figs. 8c-e, 9a). The skeleton of the outer cup surface is a very dense organization of desmas with labyrinthine interconnected pore furrows in between (Fig. 7a, c, d). The interlocking spinose outgrowths of the desmas are clearly visible, apically spinose (Fig. 7c-f), and the globular centers of the desmas are not visible (though possibly hidden deeper in the skeleton) (Fig. 7c-e). Skeleton of the inner surface is similar with a dense desma network, and globular centers of desmas are clearly visible (Fig. 8b-d), with 3-6 main arms that articulate with centers of more internally located desmas (Fig. 8c). In 
Fig. 5 Vetulina indica sp. nov. ac inner surface of cup showing numerous densely distributed small openings (?ostia) and microstyles protruding from the ectosome (c), $\mathbf{d}-\mathbf{f}$ view of the inner surface after removal of organic material by acid treatment showing dense desmas (sphaeroclones) of the choanosomal skeleton. Note numerous densely distributed openings and that the sphaeroclonar characters of the desmas are not easily seen. Scale bars (a) $500 \mu \mathrm{m}$, (b) $200 \mu \mathrm{m}$, (c) $50 \mu \mathrm{m}$, (d) $1 \mathrm{~mm}$, (e) $200 \mu \mathrm{m}$, (f) $100 \mu \mathrm{m}$
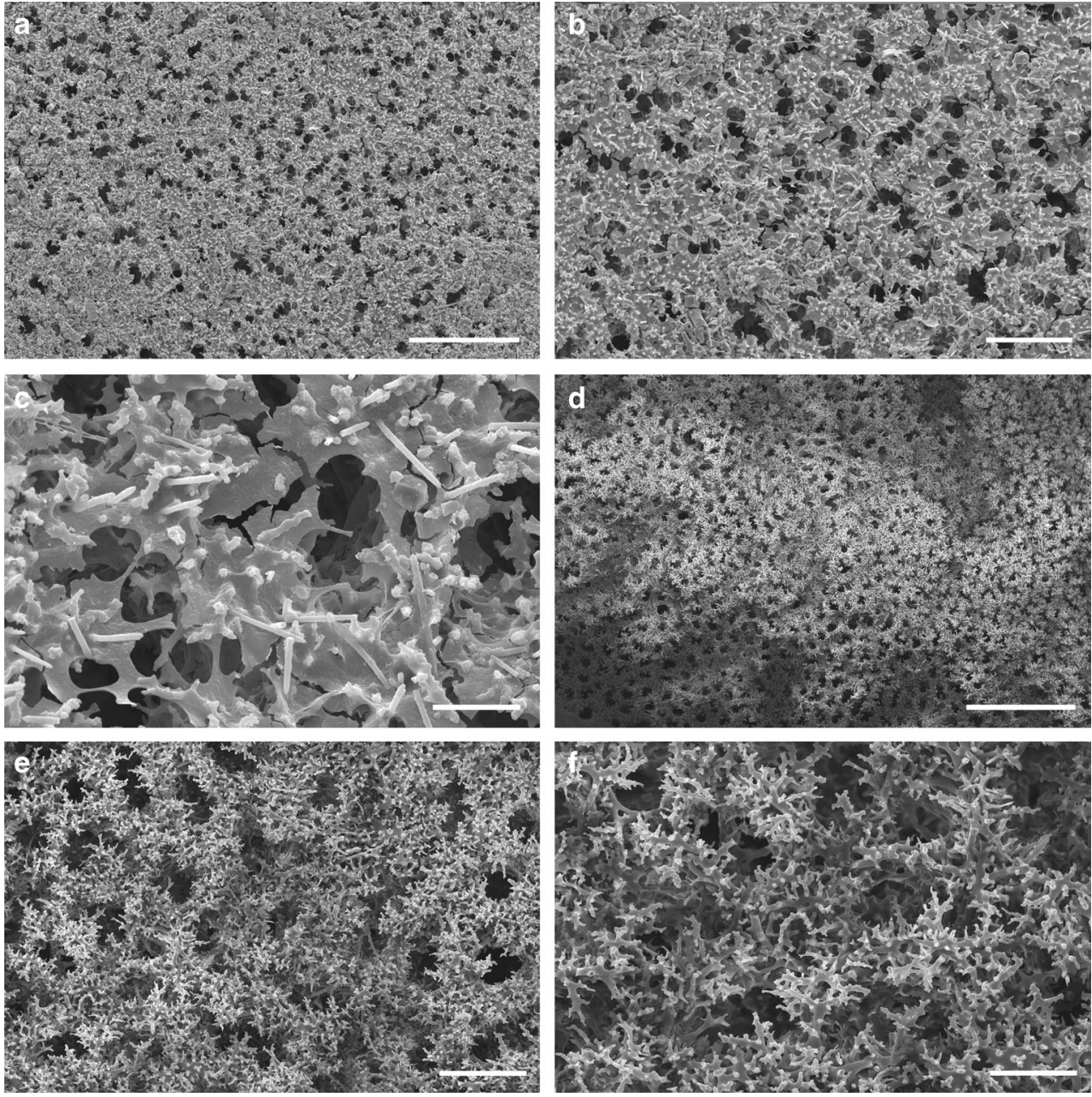

mature desmas, arborescent outgrowths covered by rare minute spine-like processes occur mainly on the globular center and to a lesser degree on desma arms (Fig. 8c, d). Immature desmas interspersed between adult desmas show a hole in the center (Figs. 8f, 9b). In the interior of the choanosomal skeleton, the globular centers are covered with low smooth tubercles rather than arborescent outgrowths (Fig. 8e).

Microscleres straight to slightly curved and isodiametric (equal thickness along the spicule) styles (Fig. 9c-g), measuring 75-200 $\mu \mathrm{m}$ in length and 3-7 $\mu \mathrm{m}$ thick. Long mucronate pointed tips (Fig. 9e-g). Styles are sparsely distributed (perpendicular) in the ectosomal membrane and concentrated around the ostia.

Ecology: The sponge occurred on the outer shelf where the bottom type included cobbles, boulders, rock outcrops, rubble, and rippled muddy sand.

Distribution: Off Broome, northwestern Australia, Indian Ocean.
Fig. 6 Spicules of Vetulina indica sp. nov.: a desma from the surface, $\mathbf{b}, \mathbf{c}$ desmas from the interior of the choanosmal skeleton, d, e microstyles. Scale bars $40 \mu \mathrm{m}$

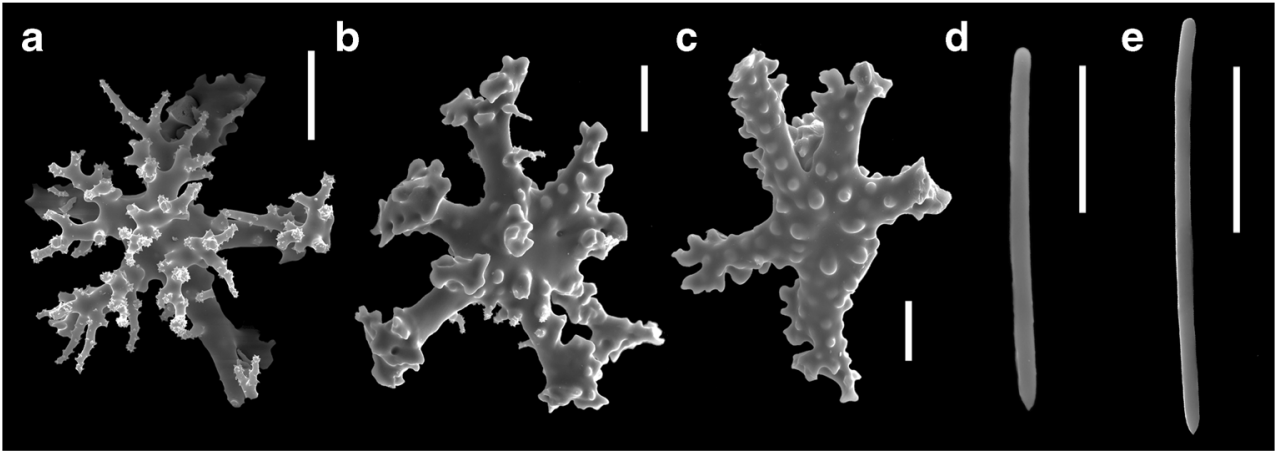



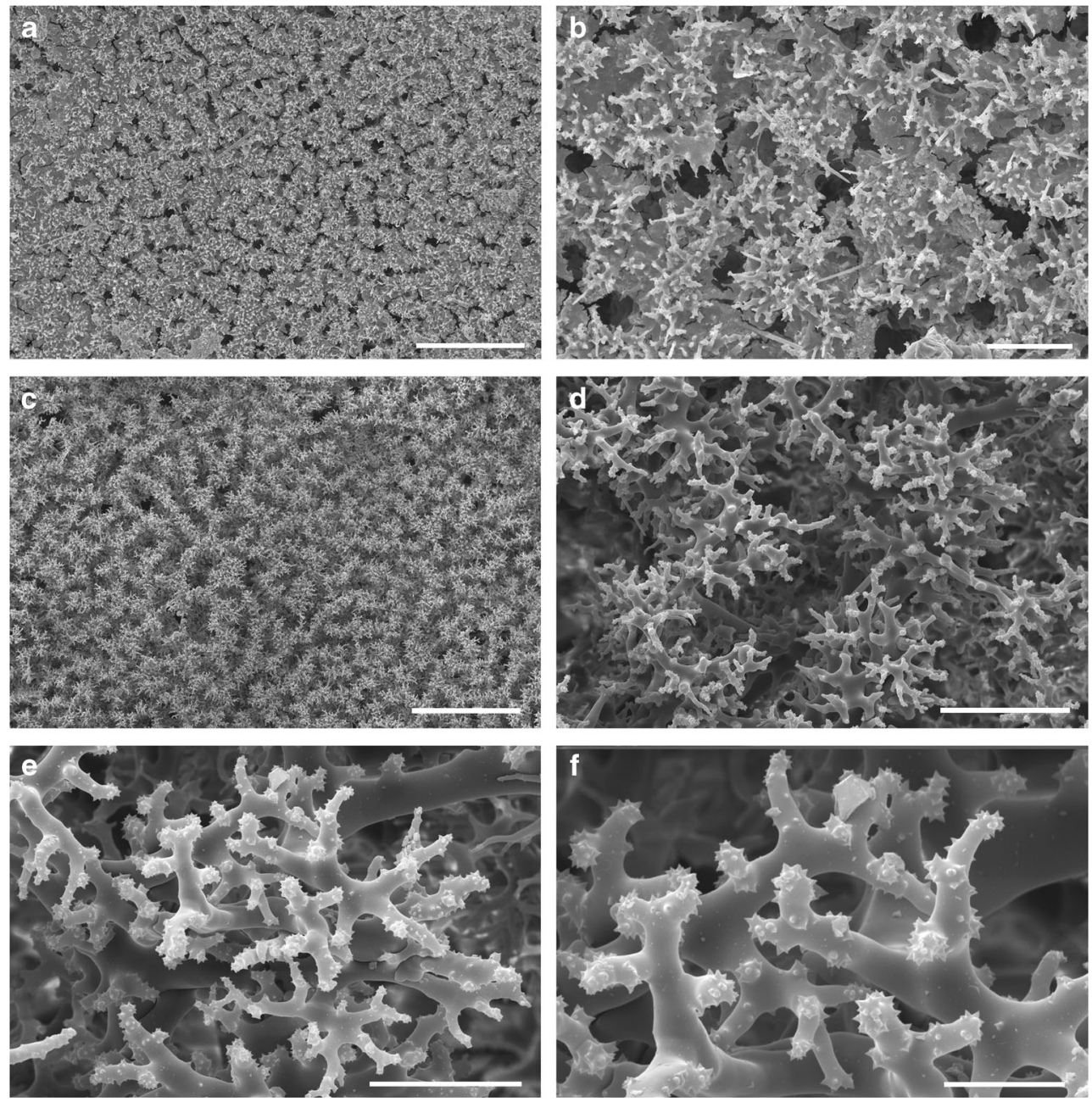

Fig. 7 Vetulina rugosa sp. nov.: a, b outer surface view (note that the character of this surface is similar to the inner surface of $V$. indica sp. nov.). Note numerous densely distributed small openings (?ostia) in the choanosome bounded by membranes and microstyles (b) protruding from the dermal membrane, $\mathbf{c}-\mathbf{f}$ details of the outer surface after removal of organic

Etymology: Named 'rugosa' for the very rugose internal walls of this species.

Remarks: This new species differs from Vetulina stalactites in morphology. It has thinner walls $(0.5 \mathrm{~cm}$ compared to $0.5-1.0 \mathrm{~cm}$ ) and the inner cup surface is strongly rugose in contrast to the even inner surface of $V$. stalactites, which only has growth lines.

All three known species have very similar choanosomal sphaeroclones that differ mostly in minor details, such as degree of tuberculation and density of arborescent outgrowths of the sphaeroclones. The shape and size of the microstyles are very similar, thus study of the spicule complements alone would not differentiate these species. Vetulina rugosa $\mathrm{n}$. sp. is clearly different from both other species because of the distinctive ridged inner cup walls, as well as the different pattern of canal openings on the surface. In lithistid demosponges, such characters allow for

material by acid treatment showing dense desmas (sphaeroclones) of the choanosomal skeleton. Note numerous densely distributed small openings in the ectosome and the complex spine bearing branched outgrowths of the desmas hide the sphaeroclonar detail. Scale bars (a) $500 \mu \mathrm{m}$, (b) $100 \mu \mathrm{m}$, (c) $500 \mu \mathrm{m}$, , (d) $100 \mu \mathrm{m}$, (e) $50 \mu \mathrm{m}$, (f) $20 \mu \mathrm{m}$

species differentiation. In addition, this species has a disjunct distribution to $V$. stalactites. The species occurs $550 \mathrm{~km}$ to the south of Ashmore Reef where $V$. indica $\mathrm{n}$. sp. was collected.

\section{Discussion}

All three known species of Vetulina are very similar, in gross morphology as well as in general spiculation, but they clearly differ in details. Vetulina stalactites is a thick-walled open cup with the type collected from $180 \mathrm{~m}$ depth in the Caribbean, and additional material recorded from $220 \mathrm{~m}$ at Martinique (Pomponi et al. 2001). It has sphaeroclonar desmas, a type of desma found only in the Vetulinidae and Sphaerocladina. The two new species are very similar to the type of the genus by having a cup morphology; however, in both instances, the 
Fig. 8 Vetulina rugosa sp. nov.: a inner surface view of the oscules showing microstyles extending into the openings, $\mathbf{b}-\mathbf{d}$ outer surface after removal of organic material by acid treatment showing dense desmas (sphaeroclones) of the choanosomal skeleton. Note the clearly visible spherical center with 3-4 thick principal arms (clades) and numerous long conical branching outgrowths, with tips covered in spines, occurring on the upper surface of the sphaeroclones, e desma skeleton from the inner wall (many broken). Note the sphaeroclones are larger and covered only with lower tubercles, $\mathbf{f}$ upper surface of inner wall showing immature sphaeroclonar desmas with characteristic hole in the center (instead of axial canal) between mature sphaercolones. Scale bars (a) $100 \mu \mathrm{m}$, (b) 200um, (c) $50 \mu \mathrm{m}$, (d) $50 \mu \mathrm{m}$, (e) $200 \mu \mathrm{m}$, (f) $50 \mu \mathrm{m}$
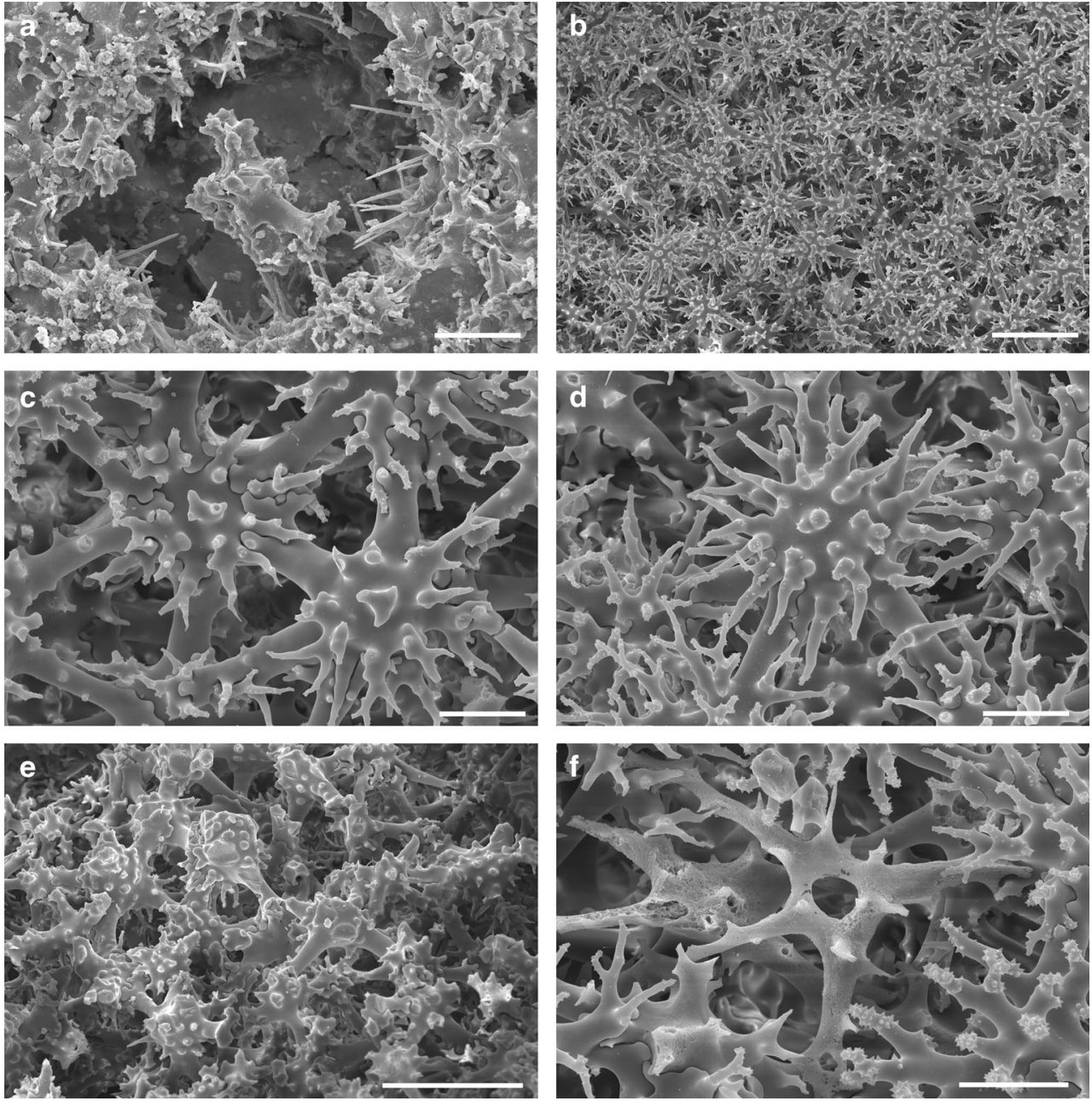

walls are thinner than in the type species. Additionally, V. rugosa n. sp. has a distinctive rugose interior surface, which is not interpreted as an environmental/population effect. The species in this study also differ in the pattern of canal openings on the sponge surface (see descriptions above); such differences usually have specific significance in living lithistid demosponges. Both of the Indian Ocean species are found at slightly shallower depths (95 and $108 \mathrm{~m}$ ) than $V$. stalactites ( $200 \mathrm{~m})$, and both have small styles not previously reported for the genus. Pomponi et al. (2001) described the habitat in Martinique where $V$. stalactites was recorded as rock and sand slopes with boulders or rock outcrops. Similarly, the habitat in the Indian Ocean was either rocky substrate with a sand veneer (Ashmore) or rock outcrops and rubble with rippled muddy sand (Broome). Previous molecular analyses of the two Indian Ocean species holotypes were based on the standard COI 'Folmer' fragment ( $600 \mathrm{bp})$, showing a 1\% sequence difference, and no resolution on species level was observed in
Fig. 9 Spicules of Vetulina rugosa sp. nov.: a mature desma, b immature desma with hollow center, $\mathbf{c}-\mathbf{g}$ microstyles. Scale bars $40 \mu \mathrm{m}$

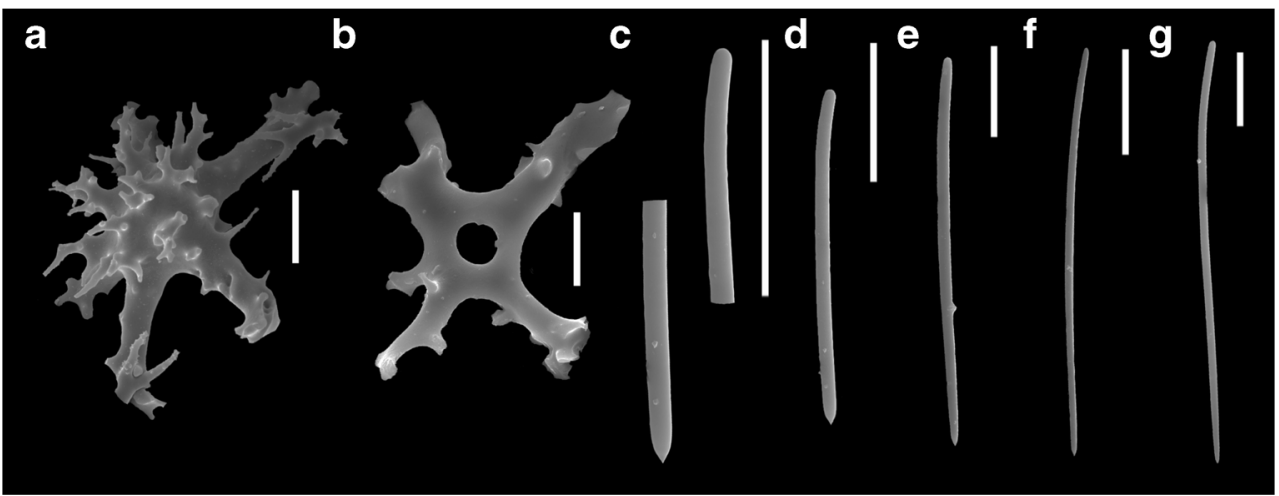


the generated gene tree (Schuster et al. 2015, fig. 5). In this study, we additionally sequenced the extended 'Erpenbeck' fragment of the CO1 gene (Erpenbeck et al. 2006) for both published specimens (LN624212 and LN62421) (Schuster et al. 2015) in order to elucidate ambiguous sites at the $3^{\prime}$ end, which caused the $1 \%$ difference. Our result shows that the 1065-bp-long fragment of both holotypes are $100 \%$ identical. Thus, our generated gene tree, which is based on a reduced taxa set of Schuster et al. 2015, confirms the previous findings. Presently, we are not aware of a generally accepted molecular species concept for sponges and $\mathrm{CO} 1$ is known to be highly conserved in Demospongiae (Shearer et al. 2002). Therefore, our description of the two new species is based solely on morphological differences in this study.

In previous publications on recent species, Vetulinidae was considered to be closely related to the siphonidiid genus Siphonidium and azoricid genus Leiodermatium (Soest and Stentoft 1988; Gruber 1993). In fact, some records of Vetulina may be Leiodermatium as they are very similar morphologically. Both develop habitus of ear-shape to complex folded masses. Affinity with the genus Siphonidium was suggested based on the erroneous interpretation of the similarity of the desmas. However, the genera differ completely in desma characters with sphaeroclones in Vetulina and rhizoclones in Leiodermatium and Siphonidium (Pisera and Lévi 2002; Reid 2004). Kelly-Borges and Pomponi (1994) noted that Vetulina is distinctive from other lithistid orders and that it could be considered to have separate ordinal status within the Sphaerocladina. Pisera and Lévi (2002) noted the similarity of Vetulinidae to Mesozoic sphaerocladine lithistids, suggesting Vetulina may be the only extant genus of this lineage. Schuster et al. (2015) formerly placed Vetulinidae into its own order Sphaerocladina. Until the discovery of these two new species, Vetulina was a monospecific genus in the monogeneric Vetulinidae.

In paleontological textbooks, the family Vetulinidae includes about 10 genera of Mesozoic (Jurassic and Cretaceous), and one Paleogene (the only record from the Eocene of Italy; Frisone et al. 2016) genus, which were mostly massive in habit, bearing sphaeroclonar desmas and without (known) ectosomal spicules. The palaeontological suborder Sphaerocladina, aside from Vetulinidae, also included forms grouped in the family Lecanellidae which had astroclonal desmas that differ considerably in form (and greater size than typical sphaeroclones), and in some cases typical dichotrianes as ectosomal spicules (Pisera 1997). This latter observation clearly indicates that fossil Sphaerocladina, as defined in the Treatise (Reid 2004), are a polyphyletic group, and Lecanellidae belongs to the Tetractinellida Marshall 1876, and here we formally make this reallocation.

The affinities of Vetulina are unclear. Lévi (1960) considered a possible affinity of Vetulina with Crambe (Poecilosclerida: Crambeidae) due to the fact that both possess sphaeroclonar desmas. Kelly et al. (2003) found that the
Fig. 10 Bayesian Inference (MrBayes, GTR+G+I model) phylogeny of a reduced taxa set of Schuster et al. 2015 including additional sequences of various spongillids showing 91-92\% similarity to Vetulina based on the CO1 'Folmer + Erpenbeck' fragments. The maximum likelihood (RAxML) analysis is congruent. Numbers above branch lengths correspond to posterior (left) and bootstrap (right) support values. New species of Vetulina are in bold

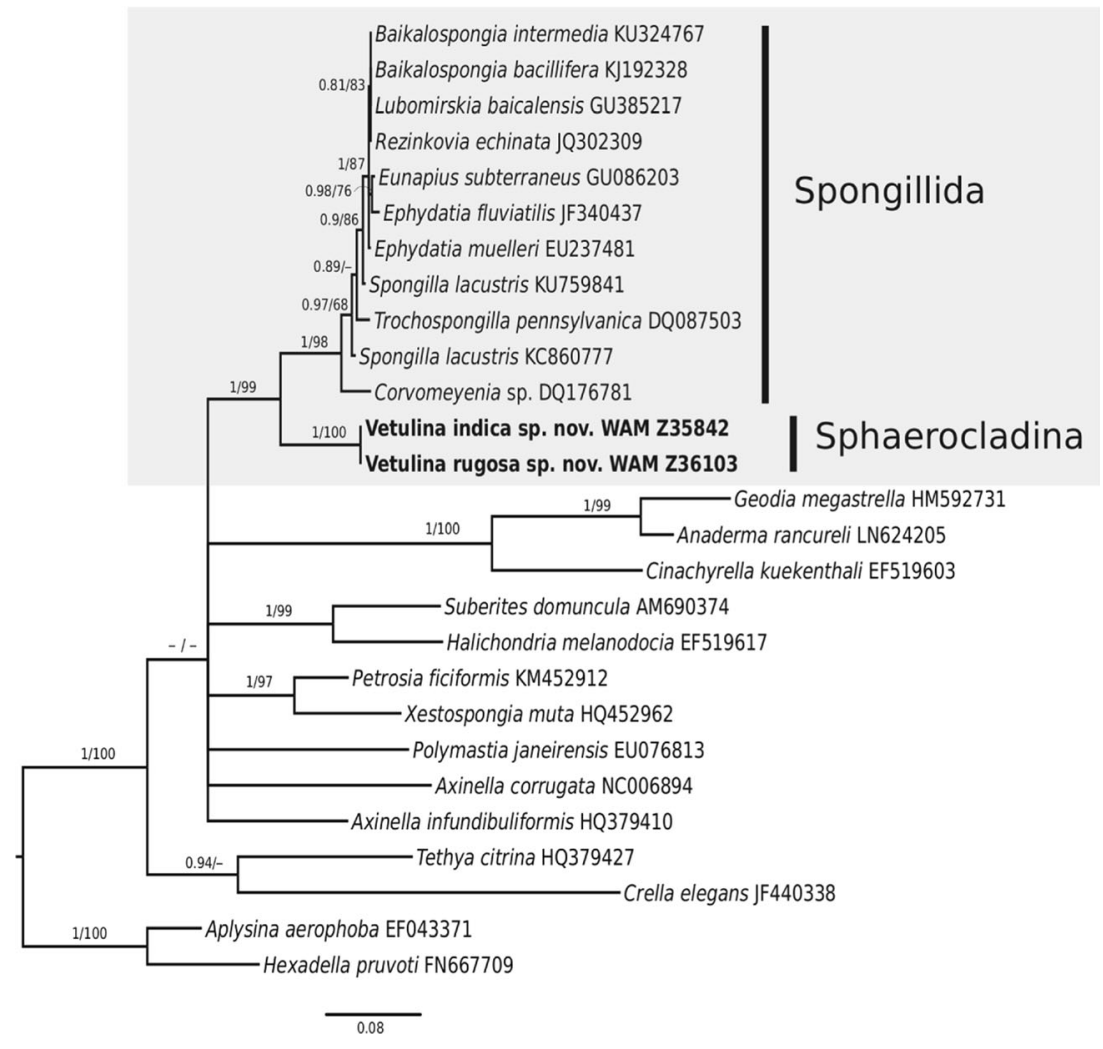


desmas of the fossil species $V$. oamaruensis Hinde and Holmes (1892) resembled the desmas of a species of Crambe from northern New Zealand, suggesting conspecifity. We consider the affinity of desmas between these two genera to be the result of convergence, as molecular studies have indicated that Crambe is very distant from Vetulina (Schuster et al. 2015).

More recently, the Sphaerocladina Schrammen 1924, based on molecular data (18S) from the type species $V$. stalactites and Vetulina sp., and the Vetulinidae are considered to be sister to freshwater sponges (Spongillida) (Redmond et al. 2013). The phylogenetic affinity of the Vetulina being sister to freshwater sponges is further corroborated by molecular data on the newly described species based on CO1 (Schuster et al. 2015; present study) (Fig. 10). This phylogenetic affinity is very surprising as the two groups have no morphological, skeletal, spicule complements, or ecological features in common. Vetulina is a deep water marine genus, while Spongillida are freshwater sponges. Spongillida have mostly oxeas and rhabds as principal spicules while Vetulina (and fossil sphaerocladine sponges) have only sphaeroclones as megascleres. Thus, this close molecular affinity remains an unresolved systematics enigma and needs further investigations.

The genus Vetulina is an example of a disjunct distribution (Caribbean and Eastern Indian Ocean or even SW Pacific) also reported for some other sponges (Carvalho et al. 2015; Łukowiak 2016), brachiopods (Bitner et al. 2008; Bitner and Motchurova-Dekova 2016), ostracods (Iglikowska and Boxshall 2013) and other crustacean fauna (Jaume and Humphreys 2001; Hoenemann et al. 2013). The key event causing this species isolation is the closure of the Tethyan Seaway in the late Early Miocene (Rögl 1998). This may correspond to the reduced Mesozoic lithistid sponge (with sphaeroclonar desmas) diversity, with Vetulina now apparently the only living representative. Other examples of such relict fauna are the anchialine ostracods (Thaumatocyprididae), which colonized caves around the shallow margins of the Tethys Sea in Mesozoic times, and which were later dispersed by plate tectonic movements (Iglikowska and Boxshall 2013). All these taxa are considered to be relicts of once widely distributed populations in the ancient Tethys Sea, of which Vetulina is the newest example.

\section{Conclusions}

Prior to this study, the genus Vetulina was monospecific. This report increases the number of species in the genus from one to three. The family and genus diagnoses are emended with the confirmation that microscleres (microstyles) are present. The occurrence of these two new species of Vetulina in the Indian Ocean, while the type species is reported from the
Caribbean, is another example of relict faunas with their origin in the Tethys Sea.

Acknowledgements Specimen collection was by Mark Salotti aboard RV Southern Surveyor, on an expedition funded by Commonwealth Scientific and Industrial Research Organisation (CSIRO) Wealth from Oceans Flagship and the Australian Government Department of Environment. We thank Western Australian Museum staff Oliver Gomez for compiling Fig. 1, Bill Humphreys and Barry Wilson (research associate) for discussion on Tethyan relicts, and Franzis Althaus from CSIRO for station data. AP and MŁ were financed by the statuary funds of the Institute of Paleobiology, JF by the Western Australian Museum and AS by the German Science Foundation (DFG) (grant numbers ER 611/3-1 and Wo896/15-1).

Open Access This article is distributed under the terms of the Creative Commons Attribution 4.0 International License (http:// creativecommons.org/licenses/by/4.0/), which permits unrestricted use, distribution, and reproduction in any medium, provided you give appropriate credit to the original author(s) and the source, provide a link to the Creative Commons license, and indicate if changes were made.

\section{References}

Bitner MA, Motchurova-Dekova N (2016) Middle Miocene (Badenian) brachiopods from Yasen, northwestern Bulgaria: taxonomic composition and biogeographical significance. Neues Jahrb Geol P-A 279(1):7-22

Bitner MA, Logan A, Gischler E (2008) Recent brachiopods from the Persian Gulf and their biogeographical significance. Sci Mar 72(2):279-285

Carvalho FC, Pomponi SA, Xavier JR (2015) Lithistid sponges of the upper bathyal of Madeira, Selvagens and Canary Islands, with description of a new species of Isabella. J Mar Biol Assoc UK 95(7): $1287-1296$

Erpenbeck D, Hooper NA, Wörheide G (2006) CO1 phylogenies in diploblasts and the 'Barcoding of Life'- are we sequencing a suboptimal partition? Mol Ecol Notes 6:550-553

Finks RM, Rigby JK (2004) Paleozoic demosponges.. In: Finks RM, Reid REH, Rigby JK (eds) Treatise on invertebrate paleontology, Part E (revised), Porifera 3. Geological Society of America, Boulder, $\mathrm{CO}$ and University of Kansas Press, Lawrence, pp 9-171

Frisone V, Pisera A, Preto N (2016) A highly diverse siliceous sponge fauna (Porifera: Hexactinellida, Demospongiae) from the Eocene of northeastern Italy: systematics and palaeoecology. J Syst Palaeontol. doi:10.1080/14772019.2015.1132015

Fromont J, Althaus F, McEnnulty FR, Williams A, Salotti M, Gomez O, Gowlett-Holmes K (2012) Living on the edge: the sponge fauna of Australia's southwestern and northwestern deep continental margin. Hydrobiologia 687(1):127-142

Gruber G (1993) Mesozoische und rezente desmentragende Demospongiae (Porifera, "Lithistidae") (Palaobiologie, Phylogenie und Taxonomie). Berliner Geowissensch Abh E 10:1-73

Hinde GJ, Holmes WM (1892) On the sponge remains in the Lower Tertiary strata near Oamaru, Otago, New Zealand. J Linn Soc 24:177-262

Hoenemann M, Neiber MT, Humphreys WF, Iliffe TM, Li D, Schram FR, Koenemann S (2013) Phylogenetic analysis and systematic revision of Remipedia (Nectiopoda) from Bayesian analysis of molecular data. J Crust Biol 33(5):603-619

Iglikowska A, Boxshall GA (2013) Danielopolina revised: Phylogenetic relationships of the extant genera of the family Thaumatocyprididae (Ostracoda: Myodocopa). Zool Anz 252:469-485 
Jaume D, Humphreys WF (2001) A new genus of Epacteriscid Calanoid copepod from an Anchialine Sinkhole on Northwestern Australia. J Crust Biol 21(1):157-169

Kelly M (2007) The marine fauna of New Zealand: Porifera: Lithistid Demospongiae (rock sponges). NIWA Biodivers Mem 121:100

Kelly M, Lee D, Kelly S, Buckeridge JS (2003) A recent sponge, Pleroma aotea Kelly ("Order" Lithistida: Family Pleromidae), in the late Eocene Ototara Limestone of Otago, New Zealand. New Zeal J Mar Freshw 37:129-148

Kelly-Borges M, Pomponi SA (1994) Phylogeny and classification of lithistid sponges (Porifera: Demospongiae): a preliminary assessment using ribosomal DNA sequence comparisons. Mol Mar Biol Biotechnol 3:87103

Lendenfeld R von (1903) Porifera. Tetraxonia. In: Schulze FE (ed) Das Tierreich. 19. Friedländer, Berlin, pp 1-168

Lévi C (1960) Les spongiaires a desmes asteroides. Bull Inst océanogr (Monaco) 1179:1-9

Łukowiak M (2016) Spicular analysis of surficial sediments as a supplementary tool for studies of modern sponge communities. Helgol Mar Res 70:5. doi:10.1186/s10152-016-0459-6

Marshall W (1876) Ideen über die Verwandtschaftsverhältnisse der Hexactinelliden. Z Wiss Zool 27(1):113-136

Mehl D, Fürsich FT (1997) Middle Jurassic Porifera from Kachchh, western India. Palaeontol Z 71:19-33

Moret L (1926) Contribution a l'etude des spongiaires siliceux du Cretace superieur francais. Mem Soc Geol Fr 5:1-327

Morrow C, Cárdenas P (2015) Proposal for a revised classification of the Demospongiae (Porifera). Front Zool 12:7

Pisera A (1997) Upper Jurassic siliceous sponges from the Swabian Alb: taxonomy and paleoecology. Palaeontol Pol 57:1-216

Pisera A (2002) Fossil Lithistids: an overview. In: Hooper JNA, Van Soest RWM (eds) Systema Porifera. Kluwer/Plenum, New York, pp 388-402

Pisera A, Lévi C (2002) Family Vetulinidae Lendenfeld. In: Hooper JNA, Van Soest RWM (eds) Systema Porifera. Kluwer/Plenum, New York, pp 363-365

Pomponi SA, Kelly M, Reed JK, Wright AE (2001) Diversity and bathymetric distribution of lithistid sponges in the tropical western Atlantic region. Bull Biol Soc Wash 10:344-353

Redmond NE, Morrow CC, Thacker RW, Diaz MC, Boury-Esnault N, Cárdenas P, Hajdu E, Lôbo-Hajdu G, Picton BE, Pomponi SA,
Kayal E, Collins AG (2013) Phylogeny and systematics of Dempospongiae in light of new small-subunit ribosomal DNA (18S) sequences. Integr Comparat Biol 53:388-415

Reid REH (2004) Mesozoic and Cenozoic lithistid sponges: Dicranocladina, Pseudorhizomorina, Didymorina, Helomorina, Megamorina, Megarhizomorina, Sphaerocladina and order and suborder uncertain. In: Finks RM, Reid REH, Rigby JK (eds) Treatise on invertebrate paleontology, Part E (revised), Porifera 3. Geological Society of America, Boulder, CO \& University of Kansas Press, Lawrence, pp 239-317

Rögl F (1998) Palaeogeographic considerations for Mediterranean and Paratethys seaways (Oligocene to Miocene). Ann Naturhist Mus Wien 99A:279-310

Schmidt O (1879) Die Spongien des Meerbusen von Mexico. I Abt. Lithistiden. I Heft. G. Fischer, Jena

Schrammen A (1924) Die Kieselspongien der oberen Kreide von Nordwestdeutschland. III. und letzter Teil. Monogr Geol Paläont (1), 2:1-159

Schuster A, Erpenbeck D, Pisera A, Hooper J, Bryce M, Fromont J, Wörheide G (2015) Deceptive desmas: molecular phylogenetics suggests a new classification and uncovers convergent evolution of lithistid demosponges. PLOS ONE 10(1):e116038

Shearer TL, van Oppen MJH, Romanos SL, Wörheide G (2002) Slow mitochondrial DNA sequence evolution in the Anthozoa (Cnidaria). Mol Ecol 11:2475-2487

Soest RWM van, Stentoft N (1988) Barbados deep-water sponges. Studies on the Fauna of Curaçao and other Caribbean Islands 70: $1-175$

Soest RWM van, Boury-Esnault N, Vacelet J, Dohrmann M, Erpenbeck D, De Voogd NJ, Santodomingo N, Vanhoorne B, Kelly M, Hooper JNA (2012) Global diversity of sponges (Porifera). PLoS ONE 7(4): e35105

Sollas WJ (1885) On Vetulina stalactites (O.S.) and the skeleton of the Anomocladina. Proc R Irish Acad 4(4):486-492

Sollas WJ (1888) Report on the Tetractinellida collected by H.M.S. 'Challenger' during the years 1873-1876. 25(63). In: Report on the Scientific Results of the Voyage of H.M.S. 'Challenger' during the years 1873-76. Zoology, London, Edinburgh, Dublin, pp 1-458

Zittel KA (1877) Studien über fossile Spongien. I: Hexactinellidae. Abh Math-Phys Kl, K Bayer Akad Wiss 13(1):1-63 